\title{
Research of Accounting Talent Cultivation Model Based on the Strategic Alliance of Industry, University and Research Institute
}

\author{
Wenhua Wang ${ }^{1} \& \mathrm{Xia} \mathrm{Dai}^{2}$ \\ ${ }^{1}$ School of Economics and Management, Changzhou University, Changzhou, China \\ ${ }^{2}$ Jiandong College, Changzhou, China \\ Correspondence: Wenhua Wang, School of Economics and Management, Changzhou University, Changzhou \\ 213164, China.E-mail: jgykjx@126.com
}

Received: April 13, $2012 \quad$ Accepted: May 17, $2012 \quad$ Published: July 1, 2012

doi:10.5539/ass.v8n8p121 URL: http://dx.doi.org/10.5539/ass.v8n8p121

This paper is a periodical achievement of Changzhou Science and Education Town Foundation Item K2011308, Changzhou University Education and Teaching Research Subject GJY11020024 and Educational Research Subject HDJ1102027 in Huaide College of Changzhou University

\begin{abstract}
On the basis of discussing how to construct the strategic alliance of industry, university and research institute, this paper further studies how to promote change in accounting talent cultivation model. The authors propose constructing a strategic alliance of industry, university and research institute with the employing unit as the subject and the market as the orientation and application-based accounting talents should pay attention to cultivation of theoretical quality, practical capacity and innovative capacity.
\end{abstract}

Keywords: strategic alliance of industry, university and research institute, accounting talent, cultivation model, innovative capacity

For the time being, when universities and colleges formulate the goal of talent cultivation, they attach great importance to quality cultivation of talents. Innovative talents should possess an adventurous spirit and the eagerness to resolve a problem, have the communication skills to represent their clear-cut thinking and proficient mastery of a language and have abundant and diversified experiences. With growth of the social economy and development of the education career, the accounting industry in China is also being integrated with the international society step by step. The goal of undergraduate accounting talent cultivation concentrates more on students' comprehensive capacity. Students are required to possess the innovative consciousness, the management capacity and courage of reform and adapt to the need of globalization development. Then, this article tries to conduct a research on how to construct a strategic alliance of industry, university and research institute and how to promote change in the accounting talent cultivation model.

\section{Constructing a Strategic Alliance of Industry, University and Research Institute with the Employing Unit as the Subject and with the Market as the Orientation}

The so-called strategic alliance of industry, university and research institute means that enterprise, university and research institute start out from their own development strategic goal and strategic intention and set up a relatively stable and long term cooperative partner relationship by means of equity participation or connection of contract. This sort of partner relationship combines their mutual resources or advantages and sets up a formal but non-incorporative cooperative relationship with complementarity of advantages, risk sharing, interest sharing and development together. The purpose of this partner relationship is to fulfill a common will and obtain the optimum benefit and comprehensive advantages. Strategic alliance of industry, university and research institute in accounting industry should be constructed through cooperation of significant projects with enterprise as the subject and university as the center. 


\subsection{Constructing an Accounting Innovation Platform with Enterprise as the Subject}

Construction of innovative accounting platform with the enterprise as the subject requires all parties involved to attach great importance to the issue of bottleneck in social practice and to focus on accounting difficulties in practice of enterprises. In the process of constructing an innovative accounting platform, enterprises, universities and research institutes should positively throw their scientific resources, integrate the resources of "specificity" and "complementarity", exert their joint forces to resolve and innovate the theoretical accounting problems and practical methods and to propel mature research achievements to enterprises and to apply to practical production activities and realize "the subject of enterprise" in its true sense. In the process of specific innovation, enterprises ought to give full play to their advantages in terms of economic and social information, business practice and application of method to excavate difficult, critical and basic problems in accounting practice. Personnel in universities and research institutes should make full use of their advantages in knowledge accumulation and scientific method to demonstrate related issues and realize actual combination of practice and theory through collaborative effort and exploration. Through joint construction of an innovative accounting platform, communication and interaction in cooperation will effectively enhance professional quality and scientific research capacity of related accounting talents and realize improvement of knowledge structure of practical accounting talents and theoretical accounting talents.

\subsection{Carrying out in a Deep-going Way the Cooperative Education with University as the Center}

Positive cooperation of all parties involved in industry, university and research institute and cooperative construction of talent cultivation platform seems especially important in the cooperative education in which university is the center. In order to cultivate compound accounting talents with strategic vision, in the education in which university is the center, we should emphasize communication and collaboration with enterprises and public institutions and realize diversification and stability of the platform of talent cultivation by means of institutional construction.

\subsection{Constructing an Alliance of Industry, University and Research Institute through Cooperation of Significant Projects}

Emphasis on leading by the government, facing the market demand, concentration on integration of knowledge and focus on disciplinary optimization are the basic features to implement cooperation of industry, university and research institute by centering around key projects. In the past few years, under the leading of the government and related departments, Hunan, Shanghai, Guangdong and other provinces have successively set up all kinds of characteristic accounting research bases. Under the advocate of China Accounting Society, such accounting research platforms as "China Business Working Capital Management Research Center" and so on have been established one by one. In terms of focusing on significant issues in the accounting management field, these research bases have accumulated rich cooperative experiences and have achieved delightful achievements, and have a significant role especially in cultivation of reserve accounting talents. Construction of a strategic alliance of industry, university and research institute by centering around key projects will set up a new platform for cultivation of accounting talents and will offer a new approach.

The competent department of the government and the industrial institute and association should market and integrate the high quality resources within the accounting industry by closely centering around the direction and need of the economic and social development. Significant fundamental projects and strong talent team should realize sufficient and effective collocation under the guidance of the policy and under the driving of the institute and association. As one that plays a leading role, the governmental departments at all levels have to keep watch on malposition and malfunction of the functions, grasp the key aspects, make little inteference and really play its role as a leader and bridge. In the practice of cooperation, all fields in industry, university and research institute should attach great importance to the cost, risk and quality of a project, regard planning, implementation and tracking of the project as the key of the work, insist on the basic principle of "human orientation and regarding the project as the bond", combine theory with practice, integrate learning with application and realize cultivation and improvement of independent and innovative capacity of accounting talents.

\section{To Promote Cooperation between Professional Universities and Employing Units and Propel Change of the Accounting Talent Cultivation Model}

Cultivation of accounting talent is a systematic project and cultivation of application-based accounting talents by means of strategic alliance of industry, university and research institute is a great innovation and progress of the model of accounting talent cultivation. As a newly born object, it has proposed brand-new requirements for the university that is traditionally regarded as the major battlefield of accounting talent cultivation, the research institute that is traditionally regarded as the backbone of innovative knowledge and leading power and the 
employing unit and enterprise that is traditionally regarded as the subject of knowledge innovation. According to the changes in the situation, the university, enterprise and research institute ought to intensify communication and coordination and cooperate with each closely, propel together change in the model of cultivation of accounting talents and fulfill the goal of highly effective cultivation of application-based accounting talents.

\subsection{To Realize Change of the Accounting Talent Cultivation from "Single Cultivation" to "Pooling the Wisdom} and Efforts of Everyone" Based on Cooperation

The application-based accounting talents with development of service and who are able to deal with all kinds of complicated situations and have excellent management capacity have to be compound and application-based accounting talents who do not only possess complete knowledge structure and rich practical experiences, but also have perfect problem solving capacity and creative spirit. Under the great times background when the economic and social development reform and international and domestic competition becomes continuously aggravated, demand on this kind of application-based accounting talents is on a continuous increase. In the traditional practice of cultivating accounting talents, the model of cultivation of accounting talents in which university is the subject emphasizes theory and ignores practice, in which students have obviously insufficient problem solving capacity and application capacity. Therefore, change from theory to practice and then to creation needs to go through a long process of "thoroughly remoulding". As a result, the university students are unlikely to adapt to the rapid development of the economy and the society and to the requirement of the times that "time will not wait for me" from a transfer from knowledge to application. The model of cultivation of accounting talents in which enterprise is the subject follows the workshop cultivation mode of "training an apprentice" and emphasizes practice, as a result of which the theoretical quality is insufficient and the development aftereffect, knowledge quality, adaptability to changes, creative capacity and strategic vision have congenital limitations. Measured with a vision of development of the times, both of these two traditional cultivation models fail to satisfy demand of the knowledge-based economy and information-based economic times on cultivation of accounting talents. This proposes brand-new requirements for specific model of cultivation of accounting talents and the model has to change from a relatively "single, closed and independent" accounting talent cultivation model to a model of "cooperation, openness and pooling the wisdom and efforts of all". University, research institute and enterprise should collaborate mutually and cooperate closely and participate together in cultivation of accounting talents. In the process of cultivation, university should be regarded as the foundation, enterprise and employing unit should be regarded as the subject and research institute should be regarded as an important participation power, each performing its function and supplementing each other for a better job of cultivation of application-based accounting talents. Cultivation of application-based accounting talents should emphasize "learn to use, use by learning, use as the purpose, learning and use with full vigor, combining learning and use and emphasis on innovation". We should set up a high quality application-based accounting talent team by means of cultivating application-based and use-oriented accounting talents.

\subsection{To Strengthen Theoretical Quality of Application-based Accounting Talents Based on Institutions of Higher Learning}

In the process of cultivating application-based and compound accounting talents who "are cooperative and open-minded and pool the wisdom and efforts of everyone", university is always the foundation and major battlefield for cultivation of accounting talents. Cultivation of talents is always and should also be the most basic and important function of the university. In the process of cultivating application-based accounting talents, the university should further define the specific goal of cultivating application-based accounting talents, reform the curriculum structure, optimize the curriculum setting, enrich the content of teaching, update the knowledge system, continue to renovate the teaching method, bring the cultivation standard of application-based accounting talents always into correspondence with the requirement for development of the times and keep the knowledge structure of application-based accounting talents in pace with progress of the times and updating of the knowledge according to "Medium and Long-term Talent Development (2010-2020)", "Accounting Talent Planning" and requirements of educational reform in university. It is not only necessary to ensure the width and depth of imparting of knowledge and that application-based talents possess solid theoretical quality, but is also necessary to guarantee the frontier and advancement of knowledge, keep the pace of knowledge structure of application-based accounting talents with the times, tread closely on the heels of the knowledge updating. In addition, it is also necessary to ensure organic combination of knowledge imparting and knowledge application, prevent separation of learning from use and ensure that the goal of cultivation of use-oriented and application-based accounting talents. Furthermore, it is a must to be clearly aware of the guiding role of theory in practice, come to realize the basic influence of theoretical knowledge on cultivation of the application capacity 
and innovative capacity, continue to explore new method and new approaches for highly effective theoretical basic education and better play the fundamental role of university in the cultivation of application-based accounting talents.

\subsection{To Enhance the Practical Capacity of Accounting Talents with the Subject of Employing Unit}

In the process of cultivation of application-based accounting talents, "use" is the key and is the ultimate goal. Cultivation of application-based and application-oriented accounting talents with combination of learning and use and service development requires the job of talent cultivation to, on one hand, always and everywhere focus on "use" and to always put cultivation of "application and innovative capacity" as the center. And on the other hand, the job of talent cultivation is required to put "use" into practice, put cultivation of talents into the specific enterprises, place the job of talent cultivation at the first line of the practice of enterprises, and apply all abstract theoretical knowledge that has been learnt in the classroom into all kinds of specific jobs. It is necessary to learn by doing, do by learning, learn and apply with full vigor the knowledge that has been learnt and really transfer knowledge to the application capacity and to active productivity and creativity through the specific practical process of the cultivation of application-based accounting talents.

In the meantime, the major battlefield where application-based accounting talents are used is the enterprise. Playing the role of enterprise as a subject in cultivation of application-based accounting talents also has a special effect of "going deep to the field and manufacturing in accordance with the need" in "manufacturing" this special kind of "product" of application-based accounting talents. It is not only a manifestation of the progress of the times, but is also a particular requirement of "manufacturing talents in accordance with the need" at a period of "excess of supply" and is a particular requirement for the job of cultivation of talents.

As the first line of practical production organization and the primary talent user, enterprises are supposed to take an initiative in taking part in cultivation of application-based accounting talents. Through the multiple patterns of actively taking part in joint cultivation and positively accepting social practice, we are supposed to change the first line of productive practice of enterprises into a big classroom for cultivating application-based accounting talents and the best occasion with combination of theory and practice and provide as many convenient conditions as possible for cultivation of application-based accounting talents. It is also necessary for enterprises to continue to develop and make progress in the process of cultivating application-based accounting talents and in organic combination of theory with practice.

\subsection{To Cultivate the Innovative Capacity of Application-based Accounting Talents with Research Institutes as the Major Power}

Innovation is the basic foundation to maintain the competitive strength of a country and a nation and is an inexhaustible motive force for social progress. From the perspective of international and domestic competition and the social change, knowledge is updated more and more fast, economic business becomes more and more complicated, all kinds of new situations, new conditions and new problems emerge in endlessly and innovation, change and uncertainty are not only an eternal topic of social development, but more and more become a primary pressure in human economic activities. This requires cultivation of application-based accounting talents not only to be simply confined to "be able to use", but also emphasize "use well and use actively". It is necessary to pay more attention to the capacity of application-based accounting talents in adaptability to changes and cultivation of innovative capacity, strengthen the capacity of application-based accounting talents in active knowledge innovation, their capacity in active and flexible adaptability to any complicated situation and crisis, their capacity in risk prevention and prediction, be more aware of the importance of application-based accounting talents in "creative use of knowledge" and "creation with the knowledge and skills they have learnt" and enhance the active adaptive capacity of application-based accounting talents in economic and social development. This calls for close cooperation of university, research institute and enterprise to regard research institute as an important participation power of talent cultivation and give full play to the important role of research institute in the process of talent cultivation. At the time of emphasizing "learning" and "use", it is necessary to further cultivate and enhance the knowledge creation and innovative capacity of application-based accounting talents with the help of research institute and encourage application-based talents to "use well and use actively" the knowledge they have learnt. In this process, the innovative capacity of the accounting talent team in our country is generally improved and the creativity and the competitive strength of the country and the nation is consolidated.

\section{References}

Fan, Caiping, \& Jin, Benneng. (2010). Research on the Construction of the Strategic Alliance for the Industry-University-Research Cooperation in Anhui Province Higher Education Institutions. Journal of Anqing Teachers College (Social Science Edition), (9). 
Han, Hong. (2010). Development of Strategic Alliance of the Industry, University and Research Institute and Policy Orientation. People's Tribune, (11).

Liu, Yongze. (2004). Accounting Education and Accounting Education Research Status in China. Accounting Research, (2).

Shi, Benren. (2000). Development of Knowledge-based Economy in the $21^{\text {st }}$ Century and Change of China Accounting Education. Accounting Research, (9).

Tian, Jianguo. (2007). Discussion on Cultivation of Innovative Talents at 21 Century. Journal of Jinan Vocational College, (3).

$\mathrm{Wu}$, Qingxian, Li, Ziquan, \& Yang, Lanfang. Promoting Reform of Practical Teaching and Cultivating High-quality Innovative Talents. Journal of Nanjing University of Aeronautics \& Astronautics (Social Sciences), (3).

Zhao, Ailing. (2001). Challenge of the 21st Century Knowledge-based Economy to our Country's Education in Accounting. Journal of Northwest Normal University (Social Sciences), 38(2).

Zhou, Jialun. (2006). Cultivation of Innovative Talents and Comprehensive Quality-oriented Education of University Students. China Higher Education, (5). 